Zabytkoznawstwo i Konserwatorstwo XLIV, Toruń 2013

Roma Gordon

Instytut Zabytkoznawstwa i Konserwatorstwa WSP UMK

\title{
Problematyka konserwatorska obrazów na filcu na przykładzie „Martwej natury” Antoniego Zydronia
}

Zonserwacja obiektów sztuki nowoczesnej niesie ze sobą wiele wyzwań. artystów do pracy twórczej, chęci poszukiwań nowych rozwiązań, doprowadzily nie tylko do odejścia od tradycyjnego malarstwa przedstawieniowego, ale również do zmiany jego warsztatu. Materiały użyte przez artystów sa często przypadkowe, dobierane bez znajomości ich właściwości i technik łączenie ze sobą, stają się jedynie narzędziem do zrealizowania zamysłu artysty. Przeważnie w pracach, gdzie dzieło staje się wytworem intuicji i przekracza się granice, bo - jak stwierdził Jasper Johns - „wbrew temu, co sądziłeś, czym obraz powinien być, widzisz teraz, że może być tym albo tamtym, albo jeszcze czymś zupełnie innym"1, ważniejsza jest intencja artysty od jakości wykonania. Owa wyższość koncepcji, zaniedbanie warsztatu, nie mogło nie mieć wpływu na trwałość realizacji. W specyficznej budowie dzieł sztuki nowoczesnej istotnym problemem jest ich odporność na działanie czynników fizycznych, chemicznych oraz biologicznych, która jest często znacznie niższa w stosunku do wrażliwości sztuki dawnej. Stawia to konserwatorów przed trudnym zadaniem dotyczącym sposobu konserwacji, doboru odpowiednich środków, analizy techniki wykonania, a tak-

1 P. Krakowski, O sztuce nowej i najnowsæej, Warszawa 1981, s. 12. 
że odpowiedniej profilaktyki. W przypadku Martwej natury Antoniego Zydronia problematyka zniszczeń wynikała z zastosowania przez artystę filcu jako podobrazia, co wymusiło wielokierunkowe podejście do zagadnienia konserwacji i restauracji owej pracy, do analizy właściwości użytych materiałów w celu określenia prawidłowego postępowania ${ }^{2}$.

\section{Dzieło i jego twórca}

Antoni Zydroń ${ }^{3}$ był artysta, którego nie można przyporządkować do konkretnego kierunku czy tendencji w sztuce. Pomimo że był związany z Międzynarodowym Ruchem PHASES ${ }^{4}$ oraz Stowarzyszeniem ACTUAL ${ }^{5}$, trafne wydaje się określenie Jerzego Madeyskiego, że „Zydroń jest nie tylko surrealista. Jest również surrealista, a to nie znaczy to samo"6. Artysta już od wczesnych lat swojej twórczości zaczął poszukiwać innych środków wyrazu niż tradycyjne malarstwo przedstawieniowe. Jego ulubionymi formami stały się assemblage, które najczęściej tworzyły układ environment oraz tzw. książki-przedmioty. Wykorzystywał w nich materiały organiczne, takie jak:

2 Obraz był przedmiotem pracy dyplomowej autorki, realizowanej w latach 2009-2011 pod kierunkiem prof. dr. hab. Dariusza Markowskiego, dr Joanny Arszyńskiej, dr. Sławomira Kamińskiego w Zakładzie Konserwacji i Restauracji Sztuki Nowoczesnej Uniwersytetu Mikołaja Kopernika w Toruniu.

3 Antoni Zydroń żył w latach 1936-2001. Studiował na Wydziale Malarstwa ASP w Krakowie. Od 1970 r. był związany z obecną ASP w Poznaniu, gdzie kierował Pracownią Działań i Struktur Wizualnych, Zakładem Psychofizjologii Widzenia oraz następnie Katedrą Intermediów. Od 1981 r. był profesorem. W latach 1971-1973 pełnił funkcję prodziekana Wydziału Malarstwa, Grafiki i Rzeźby, w okresie 1973-1978 prorektora ds. nauczania, a 1978-1981 rektora. Od 1991 roku był również dyrektorem Instytutu Sztuki i Kultury Plastycznej Wyższej Szkoły Pedagogicznej im. T. Kotarbińskiego w Zielonej Górze.

4 Ruch powstał w 1951 r., zakładał kontynuację działań twórczych z pogranicza surrealizmu i abstrakcji, gdzie podstawa jest swobodna gra wyobraźni.

5 Inaczej - Centre de Documentation sur le Surrealisme z siedzibą w Paryżu - gromadzi wszystkie dokumenty związane z surrealizmem, organizuje wystawy i edytuje teksty związane z tą tematyką. Miało służyć jako „skarbiec wiedz” na temat tendencji, którymi można się inspirować. A. Zydroń był jedynym polskim członkiem.

6 Cytat umieszczony w: Encyklopedia kultury polskiej XX wieku. Od awangardy do postmodernizmu, red. G. Dziamski, Warszawa 1996, s. 304. 
kości, poroża zwierzat, korek, futro, pazury albo roślinne sploty stanowiące mocne włókna lin i sznurów. Eksperymentował także z podłożem, malując często na skórze o różnej grubości, miękkości i fakturze, wypełnionej lub ogolonej z włosia, w stanie surowym lub z plamą barwną, a także na korku (szczególnie w przypadku akwareli). Poprzez sztukę chciał stworzyć świat, który rządzi się własnymi prawami, których podstawa jest wyobraźnia, który - jak napisała Anna Jamroziakowa: „,...] jest rzeczywistością artystyczna, powstającą dzięki jego własnemu językowi i jego osobistym możliwościom kodowania [...]”ౌ .

Jednym z takich przykładów jest Martwa natura namalowana w technice mieszanej na filcu naciagniętym na krosna, która została odnaleziona w piwnicy Urzędu Miasta w Poznaniu. Obraz o wymiarach 65x78 cm należy do wczesnej fazy twórczości artysty, powstał w latach 60. lub na początku 70. XX wieku8. Możliwe, że zastosowanie nietypowego podobrazia związane było z próba zastapienia brakującego na rynku płótna (znaleziony filc wcześniej pełnił funkcję wojskowego koca). W kontekście twórczości artysty mogła to być jednak kolejna próba eksperymentu z materia, poszukiwaniem innych rozwiązań, czynienia pozornie zwykłych tematów niezwykłymi.

Tematem, jak sam tytuł wskazuje, jest martwa natura, gdzie przedmioty malowane szybkimi pociąnięciami pędzla, w sposób uproszczony i zgeometryzowany wypełniaja prawie całą kompozycję, najczęściej przyjmując owalne kształty o różnych rozmiarach. Kontrastują z nimi wertykalne linie sugerujące draperię z tyłu. Monochromatyczna i przytłumiona kolorystyka utrzymana jest w szarościach, zieleniach i brązach. W tle i dla zaakcentowania blików światła na naczyniach pojawiają się żywsze barwy zestawione z przygaszonymi kolorami całości obrazu, są to czerwono-różowe, pomarańczowe swobodne pociagnięcia, natomiast przedmioty otacza ciemny kontur. Plama barwna jest kładziona płasko, bez modelunku światłocieniowego.

7 A. Jamroziakowa, Z labiryntu w labirynt: o twórczości A. Zydronia, Poznań 1995, s. 44.

8 Wiadomo, że w latach 70. decyzją Urzędu Miejskiego w Poznaniu Biuro Wystaw Artystycznych zakupiło kilka obrazów artysty, w tym m.in. Martwa nature. 


\section{Technika wykonania}

Materiał wykorzystany na podobrazie powstał $z$ wełnianej tkaniny poddanej procesowi spilśniania (łączenia włókien w zwartą masę). Jest to tak zwany filc tkany, w którym spilśnieniu poddaje się tylko powierzchnię materiału. Pod przeplatającymi się włóknami można dostrzec splot rypsowy o gęstości $12_{\mathrm{w}} \mathrm{x} 14_{\mathrm{o}}$ na $1 \mathrm{~cm}^{2}$. Na brzegu tkaniny znajduje się ścieg charakterystyczny dla koców używanych w wojsku (jak również ciemnozielona barwa). Prawdopodobnie już na samym początku podobrazie było dziurawe. Znaczny ubytek filcu artysta podkleił tym samym materiałem, jednak bez dopasowania kształtu i wymiarów (na tzw. zakładkę z użyciem dużej ilości kleju). Podobrazie zostało naciagnięte za pomoca gwoździ na drewniane krosna z sosny, delikatnie fazowane i o sztywnym połączeniu. $\mathrm{Na}$ ich odwrocie, na górnej listwie, autor umieścił ołówkiem imię, nazwisko, tytuł obrazu, numer oraz ulicę (swój adres). Wzdłuż bocznych listew narysowano strzałki (także za pomocą ołówka). Dodatkowo na krosna została przyklejona kartka identyfikacyjna obiektu, na której pismem maszynowym podano autora, tytuł, numer („151”) i technikę („olej”). Od kartki biegnie narysowana ołówkiem strzałka, która wskazuje metalową blaszkę z napisem „B.W.A NR 195”.

Zamiast odpowiedniego przeklejenia artysta użył bardzo mocno rozrzedzonej farby o spoiwie klejowym, która miała jednocześnie pełnić funkcję zaprawy, ułatwić nanoszenie kolejnych warstw. Barwa „zaprawy” jest niejednorodna, od brunatnej po ciemnobrązowa. Powstała przez zmieszanie pigmentów czerni, czerwieni i opiłków cynku. Została naniesiona w jednej warstwie, bez wyrównania, pozostawiając gdzieniegdzie tzw. grudki, a w innych fragmentach ledwo widoczny ślad.

Obraz namalowano bez wcześniejszego podmalowania, szybko, niezbyt szczegółowo, swobodnymi pociagnięciami pędzla. Wykorzystano technikę olejną z domieszkami np. opiłków cynku, jak i suche pastele. Niektóre partie pracy zostały pokryte złotym i srebrnym sprayem, który stworzył warstwę delikatnej poświaty Kolory były mieszane zarówno na palecie, jak podczas tworzenia - na obrazie. Farbę artysta kładł impastowo, zwłasz- 
cza w partii tła, gdzie impasty przybierają odrębna formę, tworząc rodzaj reliefu. Obecna jest też farba wyciśnięta bezpośrednio z tubki. Na całej powierzchni obrazu występuja grudki, które dodatkowo wzmogły ekspresję dzieła. Naczynia są bardziej gładko malowane, gdzieniegdzie odsłaniaja podłoże. Nie wiadomo, czy przetarcia są świadomym działaniem artysty, czy sa to ubytki wynikające ze słabej adhezji i kohezji warstwy malarskiej. Dopełnieniem obrazu jest autorska rama z płaskich, drewnianych listew pomalowanych na szaro-srebrny kolor.

\section{Stan zachowania i przyczyny zniszczeń}

Podstawowym czynnikiem mającym wpływ na zniszczenia obrazu była osłabiona kohezja warstwy malarskiej i jej adhezji do podłoża. Filc użyty jako podobrazie jest materiałem bardzo chłonnym, który spowodował „wyssanie” spoiwa. Jego odpowiednie przeklejenie mogłoby zmniejszyć penetrację, jednak zastosowana przez artystę klejowa zaprawa została położona nierównomiernie, miejscami zbyt cienko. W chwili przyjęcia do konserwacji obraz wraz z krosnami był zakażony mikrobiologicznie, co było skutkiem przechowywania w pomieszczeniu o podwyższonej wilgotności. Spoiwo obecne w farbach mogło stać się pożywką dla mikroorganizmów, czyniąc warstwę malarską mniej spoistą. Krucha farba w wielu miejscach uległa odspojeniu, powodując liczne ubytki, których rozmiary powiększały się przy najmniejszym nawet dotyku lub poruszeniu obiektu. Przetarcia odsłaniające podłoże powstały zwłaszcza wzdłuż krawędzi dzieła. Część z nich, co można zauważyć, była świadomym działaniem artysty. Powierzchnia obrazu uległa silnemu zabrudzeniu. Zszarzała oraz matowa warstwa malarska unieczytelniła kompozycję, natomiast tam, gdzie farba była kładziona impastowo, widoczne są spękania wtórne.

Zniszczenia objęły również podobrazie. Na całej powierzchni filcu występują drobne ubytki, w niektórych partiach nastąpiło ścienienie podłoża do grubości około $1 \mathrm{~mm}$. Filc składa się z włókien wełnianych, stąd wymienione zmiany najprawdopodobniej są skutkiem żerowania mola włosien- 
niczka - Tineola bisselliella9 (żerujące larwy moli po przepoczwarzeniu zostawiły „wylinki” i odchody w postaci maleńkich kulek, jakby szary piasek). Zardzewiałe gwoździe, którymi był przymocowany do krosien, spowodowały liczne zniszczenia materiału na krajkach. Rozległy ubytek o owalnym kształcie podklejony przez artystę zapadł się, powodując częściowe odspojenie warstwy malarskiej wokól. $W$ lewym górnym rogu obrazu, w miejscu krosien, znajduje się podłużny ubytek powstały prawdopodobnie w wyniku działania mechanicznego. Podobrazie jest zapadnięte na skutek zbyt dużego ciężaru warstwy malarskiej oraz braku możliwości regulacji napięcia. Bezpośredni kontakt obrazu z ostrą krawędzią krosien spowodował zniszczenia na licu wzdłuż górnej listwy. Rama obrazu jest zabrudzona. Występują niewielkie ubytki w drewnie na skutek uszkodzeń mechanicznych. Gwoździe listew są zardzewiałe.

\section{Prace konserwatorskie}

Głównym celem prac konserwatorskich było zahamowanie procesów degradacji podłoża poprzez jego odpowiednie wzmocnienie oraz przywrócenie odpowiedniej kohezji warstwie malarskiej i jej adhezji do podobrazia, by zapobiec dalszemu osypywaniu. Jednak w pierwszej kolejności konieczny był demontaż obrazu z krosien oraz dezynfekcja w parach p-chloro-m-krezolu, a następnie wietrzenia pod dygestorium do czasu zaniku zapachu środka. Z lica i odwrocia delikatnie usunięto powierzchniowy brud oraz odklejono autorska łatkę. Dokładne oczyszczenie nie było możliwe z powodu osypującej się warstwy malarskiej. W niezbędnym zabiegu konsolidacji trudność

9 „Mól włosienniczek” - mały motyl nocny z rodziny molowatych, szkodnik niszczący ubrania, powszechnie znany jako mól odzieżowy albo mól ubraniowy. Długość ciała do $9 \mathrm{~mm}$, rozpiętość skrzydeł 12-16 mm. Skrzydła wąskie. Beżowo-żółtawy z lekkim połyskiem. W ciagu roku może rozwinąć się do 4 pokoleń. Zamieszkują głównie szafy ubraniowe, strychy, wnętrza odkurzaczy oraz wszelkiego rodzaju magazyny, gdzie ich larwy moga odżywiać się wełna, bawełna, przedmiotami ze skóry zwierzęcej (futra) lub włosia (peruki), jedwabiem, a także nasionami (zwłaszcza ziarnem zbóż), makka, korkiem, słomą"; Dostęp w Internecie: http://pl.wikipedia.org/wiki/M\%C3\%B31_w\%C5\%82osienniczek z dn. 10.03.2013 r. 
stanowiła grubość filcu (około 1,5 cm), która mogłaby ograniczyć penetrację środka. Zabieg postanowiono poprzedzić próbami. W tym celu przygotowano odpowiednie fragmenty filcu $\mathrm{z}$ naniesioną warstwą malarską o zbliżonych właściwościach do oryginału, na które rozprowadzono następujące środki: Akrylkleber 498 HV, Plexisol P550, Acrylharz P550, Beva 371. Do konsolidacji wybrano roztwór 15\% Bevy 371 w benzynie lakowej, który naniesiono od strony odwrocia. Zabieg przeprowadzono na stole niskociśnieniowym przy temperaturze $68^{\circ} \mathrm{C}$. Po właściwym podklejeniu warstwy malarskiej możliwe było oczyszczenie lica obrazu (benzyną lakowa). Fragmenty wykonane pastelami dodatkowo utrwalono fiksatywą w sprayu firmy Talens. Uzupełnienia drobnych ubytków podłoża wykonano poprzez mieszanie włókien filcu z 20\% roztworem Bevy 371 i wtapianie, za pomoca kautera, przy temperaturze $68^{\circ} \mathrm{C}$. W większe ubytki wklejono dopasowany kształt filcu „na styk”, zcieniano brzegi i wplatano w oryginał. Autorską łatkę również dopasowano do krawędzi ubytku, a nie jak wcześniej na tzw. zakładkę. Pomimo lokalnych reperacji całe podobrazie nadal wymagało wzmocnienia - podklejenia innym materiałem, który jednak nie zmieni charakteru obiektu. Poszukiwano tkaniny dublażowej lekkiej, cienkiej, a jednocześnie prześwitującej. Podobnie jak w przypadku konsolidacji, próby przeprowadzano na specjalnie przygotowanych podłożach. Sprawdzono różnego rodzaju siatki oraz półprzezroczyste tkaniny z włókna syntetycznego. Wybrano syntetyczną bibułkę, która ma mocne włókna, jest bardzo cienka i prześwitująca. Ze względu na użycie Bevy 371 przy konsolidacji oraz uzupełnieniach, zdecydowano o zastosowaniu tego samego środka, ale o stężeniu $40 \%$. Roztwór naniesiono za pomoca wałka na naprężoną bibułę i pozostawiono do odparowania. Po odpowiednim czasie obiekt umieszczono na stole niskociśnieniowym licem do dołu i przyłożono przygotowaną tkaninę dublażowa. Odwrocia obrazu nie pokrywano dodatkowo roztworem. Zabieg wykonano przy temperaturze $68^{\circ} \mathrm{C}$. Efekt estetyczny dublażu po zakończeniu nie był zadowalający, ponieważ spoiwo znacznie przesyciło odwrocie. Po rozdublowaniu obrazu zdecydowano o powtórzeniu zabiegu, ale licem do góry (użyto folii poliamidowej, aby nie spłaszczyć impastów obrazu), co w konsekwencji dało delikatne wzmocnienie matowa, półprzezroczystą tkanina. Miejscowe wybłyszczenia likwidowano poprzez odsączenie nadmiarów spoiwa na ciepło w bibułę filtracyjna. Krajki obrazu dodatko- 
wo podklejono tkanina z włókna szklanego na 40\% roztwór Bevy w toluenie (także na stole niskociśnieniowym).

Ze względu na obecność autorskich inskrypcji zdecydowano o pozostawieniu oryginalnych krosien, które jednak wymagały przystosowania do pełnienia swojej funkcji. Wymagało to wykonania fazy, zabezpieczenia napisów oraz zapewnienia możliwości regulacji napięcia obrazu (w narożnikach zastosowano tzw. tensory). Obraz ponownie nabito, używając wkręty i podkładki ze stali nierdzewnej.

Kolejnym wyzwaniem było odtworzenie impastowej warstwy malarskiej w miejscach ubytków, znalezienie odpowiedniej zaprawy, która po odpowiednim opracowaniu dałaby fakturę zbliżoną do oryginału. Sprawdzono akrylowe pasty oraz żele do modelowania firmy Maimeri oraz Schmincke. Wybrano Volume Pasta Per Modellare (Maimeri), czyli żywicę akrylowa w emulsji wodnej z wypełniaczem, zagęszczaczem i stabilizatorem. W przypadku ubytków brązowej zaprawy klejowej wystarczyło nanieść farbę akwarelową (van Gogh), natomiast rekonstrukcję warstwy malarskiej wykonano farbami ketonowymi firmy Maimeri, które mieszano z srebrną bronza w proszku (Schmincke), co dało efekt połysku i migotania opiłków. Pracom konserwatorskim została poddana również naklejka z krosien. Wykonano także nową ramę na wzór pierwotnej.

Odrestaurowany obraz zwrócono do Urzędu Miasta w Poznaniu.

\section{Summary}

\section{Conservation problem of the paintings on felt exemplified by case of „Still life” by Marek Zydron}

This article refers to the issues of conservation and restoration of modern and contemporary art. It deals with the problem of paintings on felt support based on the example of "Still life group" by Antoni Zydron. The artist used to create in his own technique, looking for new ways of expression, experimenting with media and materials. His still art is an oil painting with various additives like metallic filings, pastels, spray paints. Instead of linen canvas Zydroń used a blanket made of felted woolen textile as a support. Specific structure of the painting had an influence on its poor condition. The main conservation problem was flaking of paint layer. Felt is a very absorbent material which deprived the paint layer 
of its binders, causing the loss of its adhesion and cohesion. As a result of that, the colour and ground layers started detaching from the support. Moreover, the structure of the felt was weakened by common clothes moths. Damaged and thinned material could not no longer carry a weightiness of the paint layers. Conservation treatment was, in the first place, focused on inhibiting the deterioration of support and reinforcing flexibility and adhesion of painting layers. Due to the atypical technique examinations of methods and materials were carried out in order to determine optimal consolidant and lining textile. 


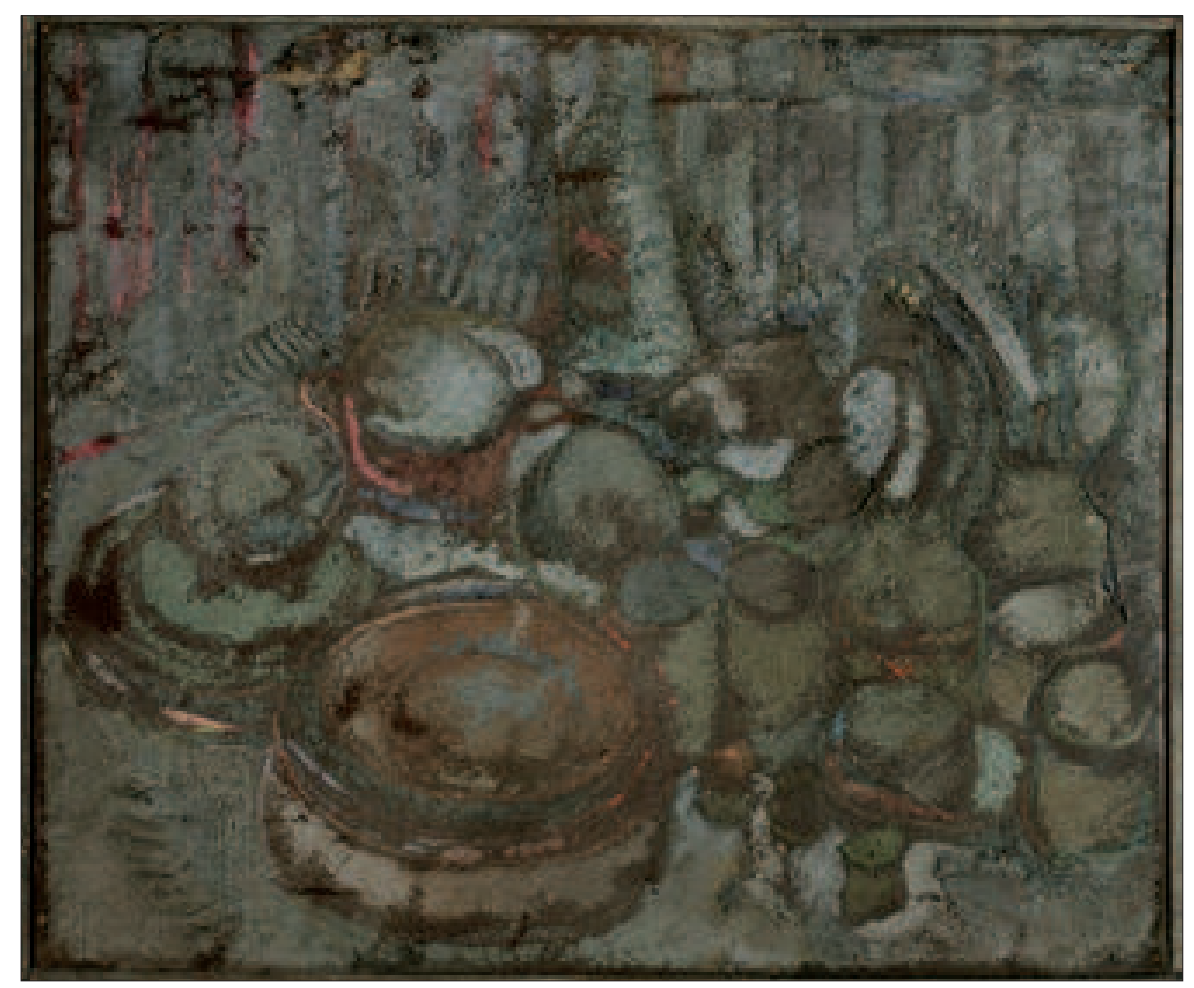

Il. 1. Lico obrazu przed rozpoczęciem prac konserwatorskich (fot. R. Gordon) 


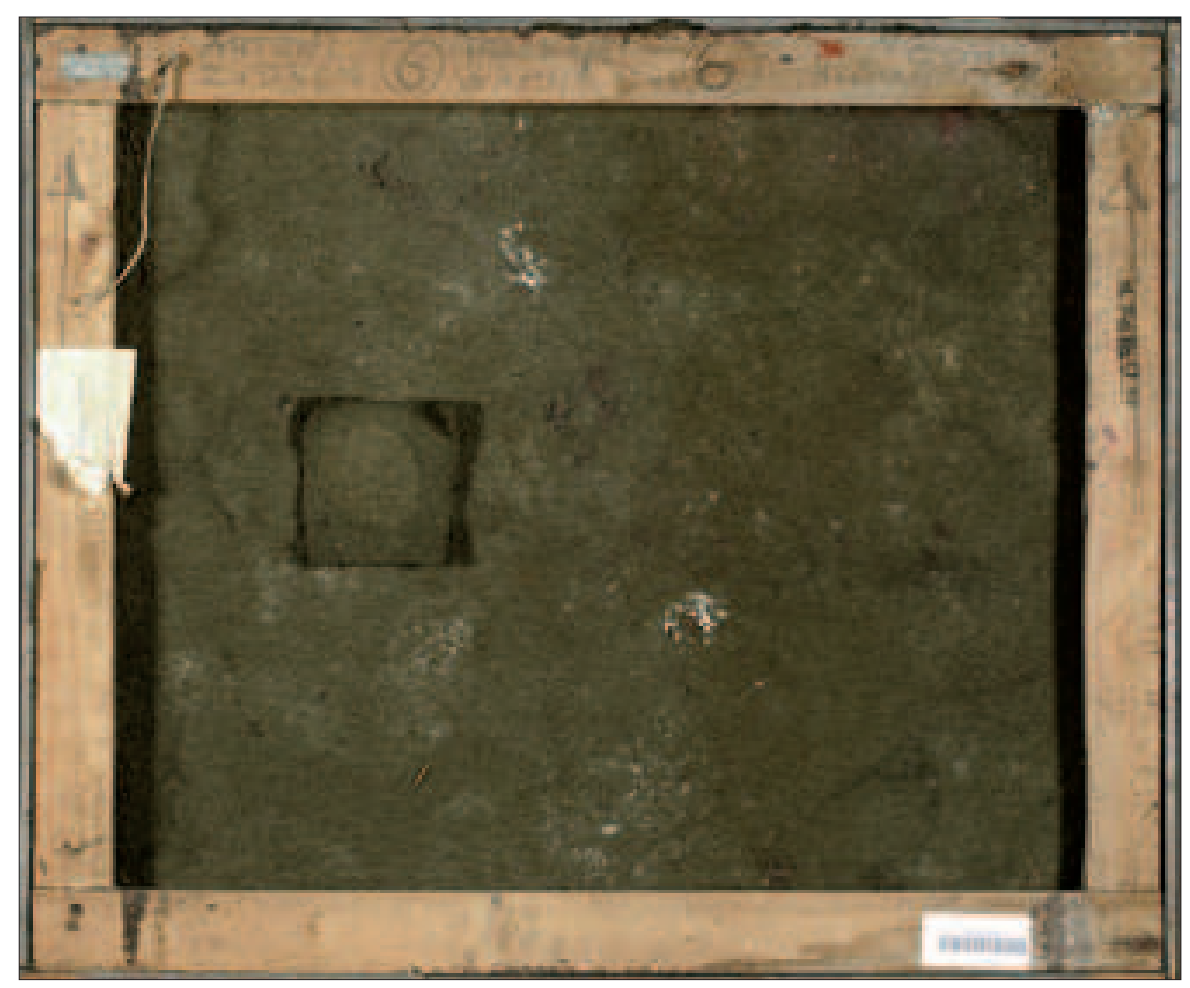

Il. 2. Odwrocie obrazu przed rozpoczęciem prac konserwatorskich (fot. R. Gordon) 


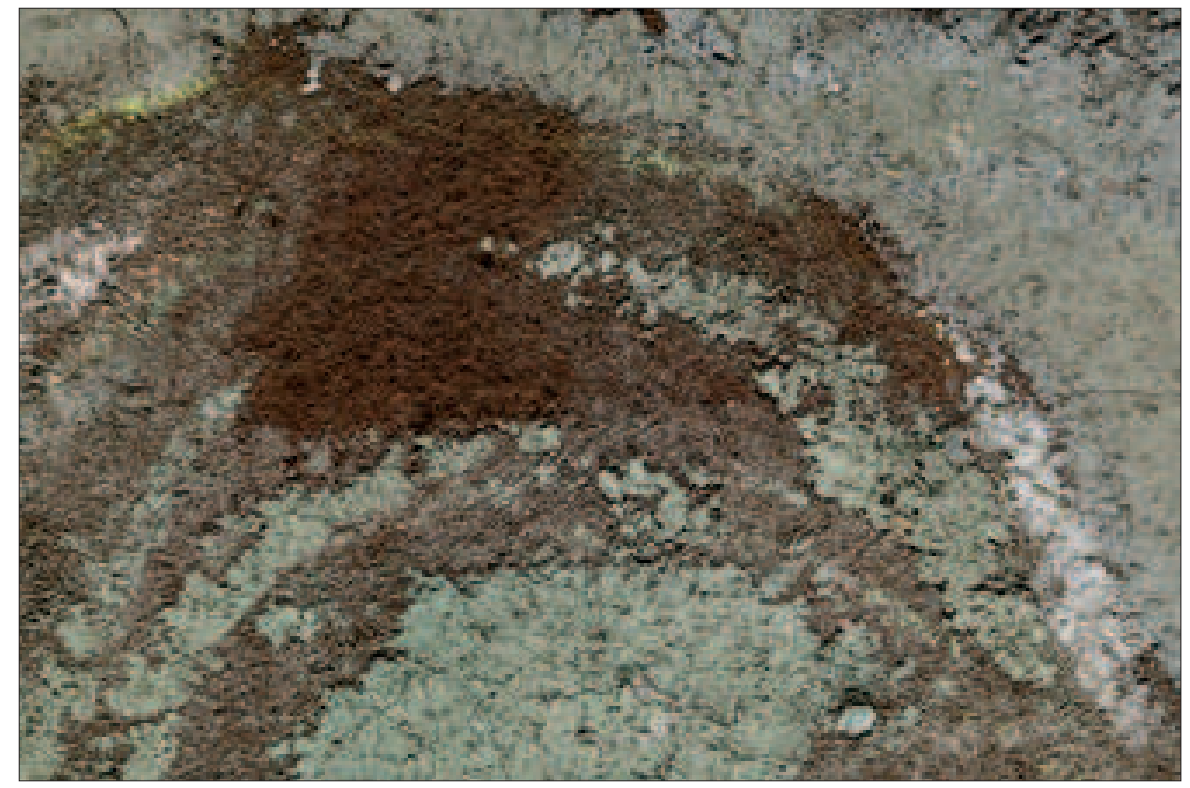

Il. 3. Osypywanie warstwy malarskiej - zbliżenie ubytku (fot. R. Gordon) 


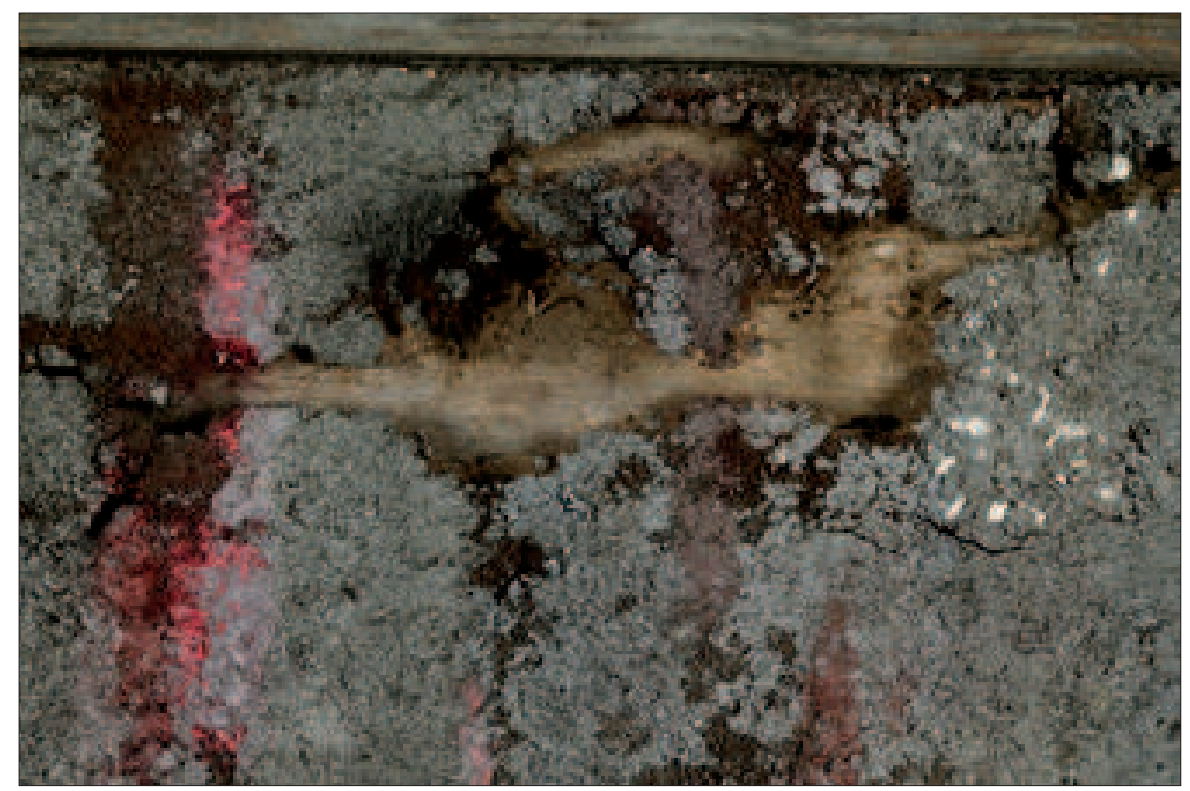

Il. 4. Ubytek warstwy malarskiej wraz z podłożem (fot. R. Gordon) 


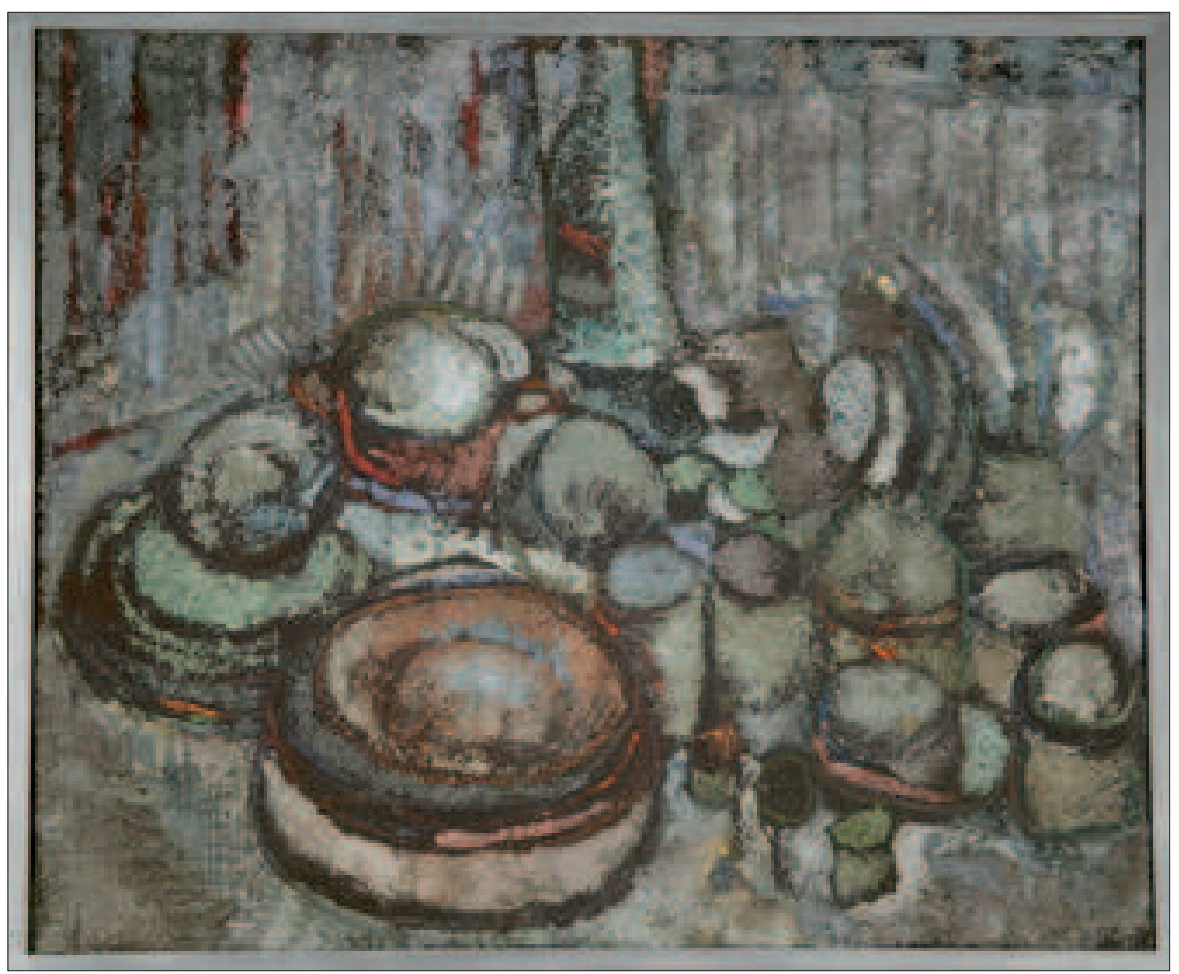

Il. 5. Lico obrazu po zakończeniu prac konserwatorskich (fot. R. Gordon) 


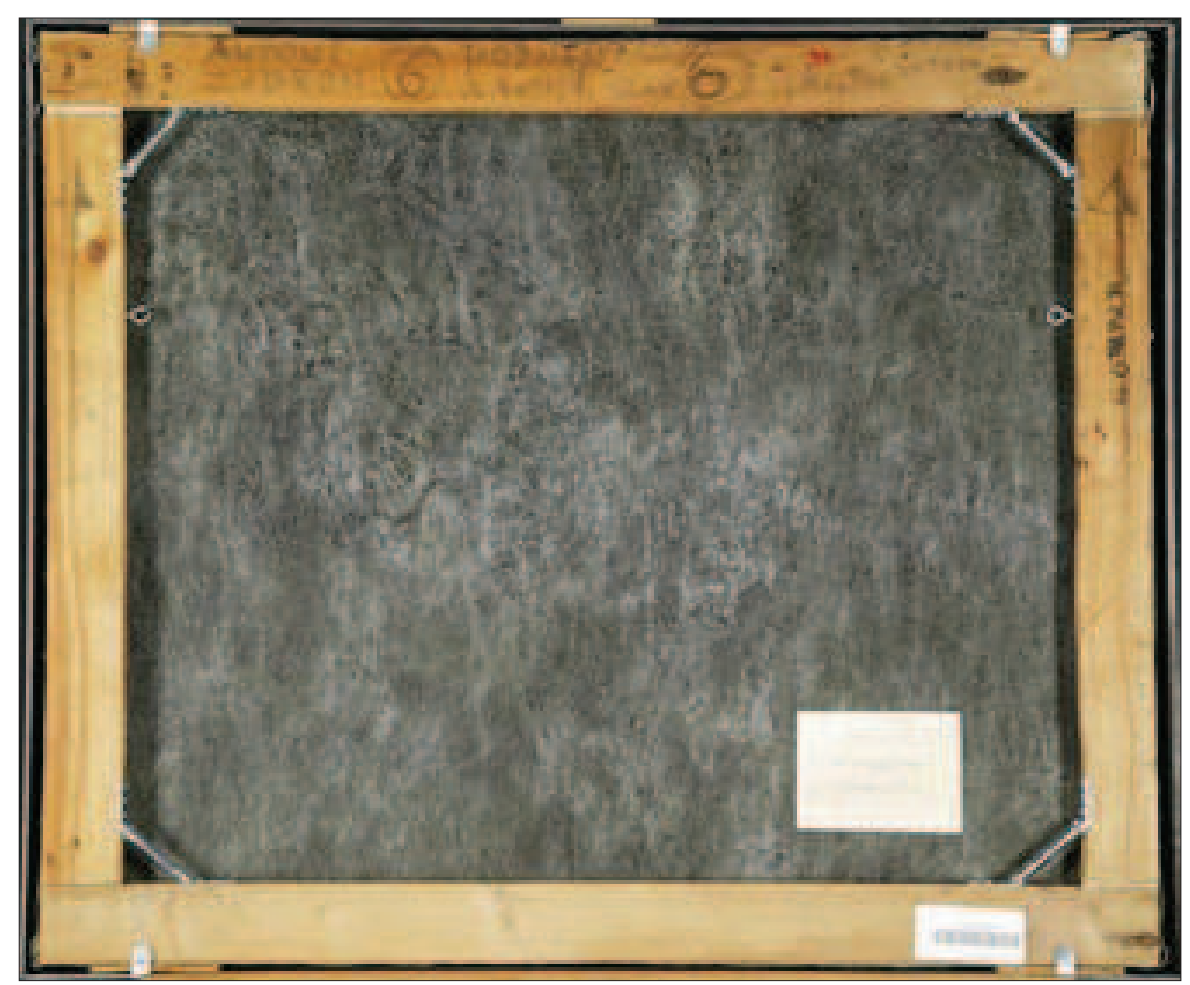

Il. 6. Odwrocie obrazu po zakończeniu prac konserwatorskich (fot. R. Gordon) 